\title{
ANALISIS PERILAKU MODEL SIR TANPA DAN DENGAN VAKSINASI
}

\author{
The Behaviour Analysis of SIR Model Without and with Vaccination \\ Julia Indah Pertiwi ${ }^{1}$, Arrival Rince Putri ${ }^{2 *}$, Efendi ${ }^{3}$, Riri Lestari ${ }^{4}$ \\ 1,2,3,4 Jurusan Matematika Fakultas Matematika dan Ilmu Pengetahuan Alam, Universitas Andalas \\ Kampus UNAND Limau Manis, Padang, Indonesia \\ e-mail:2*arrivalputri@gmail.com \\ Corresponding author*
}

\begin{abstract}
Abstrak
Vaksinasi adalah salah satu metode untuk mengendalikan sekaligus mencegah penyebaran penyakit menular. Penelitian ini mengembangkan model SIR (susceptible, infected, recovered) tanpa dan dengan vaksinasi. Perilaku solusi dari kedua model dianalisis melalui analisis kestabilan di sekitar titik-titik ekuilibriumnya. Kestabilan tersebut juga dikaitkan dengan nilai ambang batas yang menandakan apakah populasi bebas atau terinfeksi penyakit. Hasil analitik dikonfirmasi dengan hasil numerik yang disajikan pada grafik solusi dan potret fase. Hasil simulasi numerik menyimpulkan bahwa vaksinasi lebih efektif untuk menghambat penularan penyakit daripada tanpa vaksinasi.
\end{abstract}

Kata Kunci: Model SIR, Vaksinasi, Kestabilan, Nilai Ambang Batas, Numerik.

\begin{abstract}
Vaccination is one of the methods to control and prevent the spread of infectious diseases. SIR model (susceptible, infected, recovered) without and with vaccination were developed. The behavior of the solutions of the two models is analyzed through stability analysis around the equilibrium points. The stability is also associated with a threshold number indicating the population is free or infected. Analytical results are confirmed with numerical results that are presented on the graphic solution and phase portrait. The results of numerical simulations conclude that vaccination is more effective for inhibiting the transmission of the disease than without vaccination.
\end{abstract}

Keywords: SIR Model, Vaccination, Stability, Threshold Number, Numerical. 


\section{PENDAHULUAN}

Penyakit menular adalah penyakit yang dapat berpindah dari individu yang sakit ke individu yang sehat atau rentan terkena penyakit tersebut. Penyakit menular disebabkan oleh mikroorganisme seperti bakteri, virus dan jamur. Untuk beberapa penyakit menular, seperti tuberkulosis, hepatitis, malaria, cacar air, dan influenza, penularan dapat terjadi secara langsung maupun tidak langsung (melalui perantara) [1]. Penyakit menular yang menginfeksi individu dalam suatu populasi dapat menyebabkan berkurang atau hilangnya populasi dalam jumlah yang besar. Untuk itu, perlu dilakukan pengendalian terhadap penularan atau penyebaran penyakit tersebut. Salah satu cara untuk memahami fenomena penyebaran penyakit menular adalah melalui pemodelan matematika. Model matematika dapat menjadi alat yang ampuh untuk membuat kebijakan atau tindakan pengendalian yang lebih efisien $[2,3,4]$.

Model matematika yang pertama kali memperkenalkan dan membahas tentang penyebaran penyakit menular adalah model yang diusulkan oleh Daniel Bernoulli pada tahun 1760. Model ini digunakan untuk mengukur tingkat keefektifan pemberian vaksin dalam mencegah penyakit cacar [5]. Model yang dikenal dengan model SIR (susceptible, infected, dan recovered) ini membagi populasi ke dalam tiga kelompok, yaitu susceptible (populasi yang sehat, tetapi rentan terinfeksi penyakit), infected (populasi yang terinfeksi penyakit), dan recovered (populasi yang sembuh dari penyakit). Selanjutnya, Kermack dan McKendrick pada tahun 1927 membahas model SIR yang dikaitkan dengan penentuan nilai ambang batas atau basic reproduction number (bilangan reproduksi dasar) yang digunakan untuk menentukan apakah suatu populasi bebas atau terinfeksi dari penyakit [6]. Vaksinasi adalah salah satu cara untuk mengendalikan sekaligus mencegah penyebaran penyakit menular. Tingkat vaksinasi individu dalam suatu populasi, menentukan apakah populasi tersebut tahan atau tidak terhadap penyakit. Sejumlah model matematika yang mendeskripsikan mengenai penyebaran penyakit menular dengan mempertimbangkan vaksinasi yang telah dibahas oleh beberapa peneliti sebelumnya. Model penyebaran penyakit SIR dengan mempertimbangkan vaksinasi dan tingkat kekebalan yang menurun telah dibahas oleh [7]. Penelitian tersebut difokuskan pada penentuan nilai ambang batas dan solusi numeriknya. Analisis kestabilan model epidemik SIR dengan vaksinasi dibahas oleh $[8,9,10]$.

Berdasarkan latar belakang yang telah diuraikan sebelumnya, maka dalam penelitian ini akan dibahas kembali model SIR tanpa dan dengan mempertimbangkan vaksinasi yang telah dikembangkan oleh [8]. Dalam [8], mereka mempertimbangkan tingkat kelahiran dan tingkat kematian yang sama, serta membahas kestabilan global dari kedua model, sedangkan dalam penelitian ini mempertimbangkan tingkat kelahiran dan tingkat kematian yang berbeda, serta akan dianalisis perilaku solusi dari kedua model melalui analisis kestabilan di sekitar titik-titik ekuilibrium (titik kesetimbangan) yang dikaitkan dengan nilai ambang batas.

\section{METODE PENELITIAN}

Penelitian ini menggunakan langkah-langkah sebagai berikut:

1. Menjelaskan kembali model SIR tanpa dan dengan vaksinasi.

2. Menentukan titik ekuilibrium dari kedua model.

3. Meliniearisasi model melalui matriks Jacobian.

4. Menentukan nilai eigen dari matriks Jacobian untuk masing-masing titik ekuilibrium.

5. Menentukan kestabilan di sekitar titik ekuilibrium berdasarkan nilai eigen yang di peroleh.

6. Menampilkan grafik solusi dan potret fase dari model.

\section{HASIL DAN PEMBAHASAN}

\subsection{Model SIR tanpa Vaksinasi}

Model dikembangkan dengan mengelompokkan individu ke dalam tiga kelompok, yaitu susceptible, infected, dan recovered. Asumsi yang digunakan untuk mengembangkan model adalah

1. Sistem adalah sistem yang terbuka.

2. Semua individu baru (konstan) masuk ke dalam kelompok rentan.

3. Suatu individu dapat keluar dari kelompok rentan karena terinfeksi dan dapat keluar dari kelompok terinfeksi karena pulih dari penyakit. Setelah pulih, individu tersebut akan kebal terhadap penyakit.

4. Tidak ada individu yang terinfeksi menjadi rentan kembali.

5. Anggota populasi bercampur secara homogen. 
6. Tingkat kematian sama untuk ketiga kelompok individu.

Masing-masing kelompok individu dinotasikan dan didefinisikan sebagai berikut: $s$ adalah proporsi individu yang rentan, $i$ adalah proporsi individu yang terinfeksi, dan $r$ adalah proporsi individu yang sembuh, dapat digambarkan melalui diagram kompartemen di bawah ini.

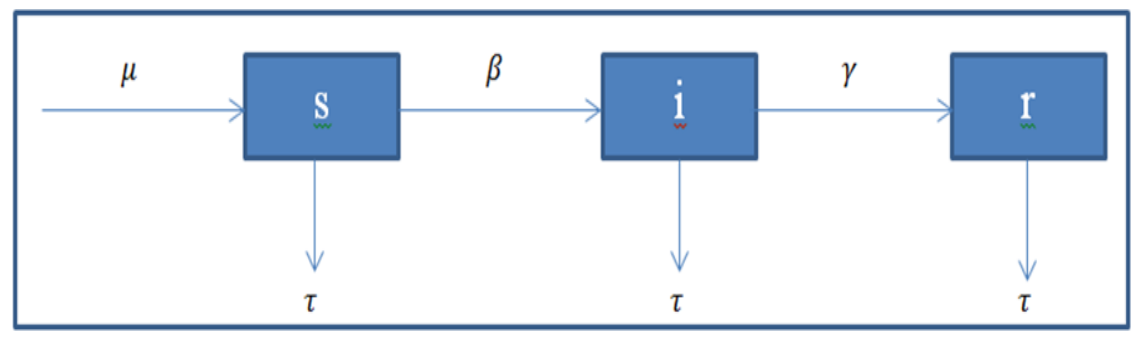

Gambar 1. Diagram Kompartemen Model SIR Tanpa Vaksinasi

Berdasarkan asumsi yang diberikan, maka model dinyatakan sebagai sistem persamaan diferensial

$$
\begin{aligned}
& \frac{d s}{d t}=\mu-\beta i s-\tau s \\
& \frac{d i}{d t}=\beta i s-\gamma i-\tau i \\
& \frac{d r}{d t}=\gamma i-\tau r
\end{aligned}
$$

dengan kondisi awal $s(0) \geq 0, i(0) \geq 0$, dan $r(0) \geq 0$. Parameter $\mu$ adalah tingkat individu baru yang masuk ke dalam populasi, $\tau$ adalah tingkat kematian, $\beta$ adalah tingkat kontak antara individu yang rentan dengan individu yang terinfeksi, dan $\gamma$ adalah tingkat kesembuhan dari individu yang terinfeksi.

\subsection{Model SIR dengan Vaksinasi}

Selanjutnya, model (1) diformulasikan kembali dengan mengasumsikan bahwa penyebaran penyakit dalam populasi dapat berkurang dengan diberikannya vaksinasi kepada individu baru yang masuk. Model SIR dengan vaksinasi dapat digambarkan melalui diagram kompartemen berikut.

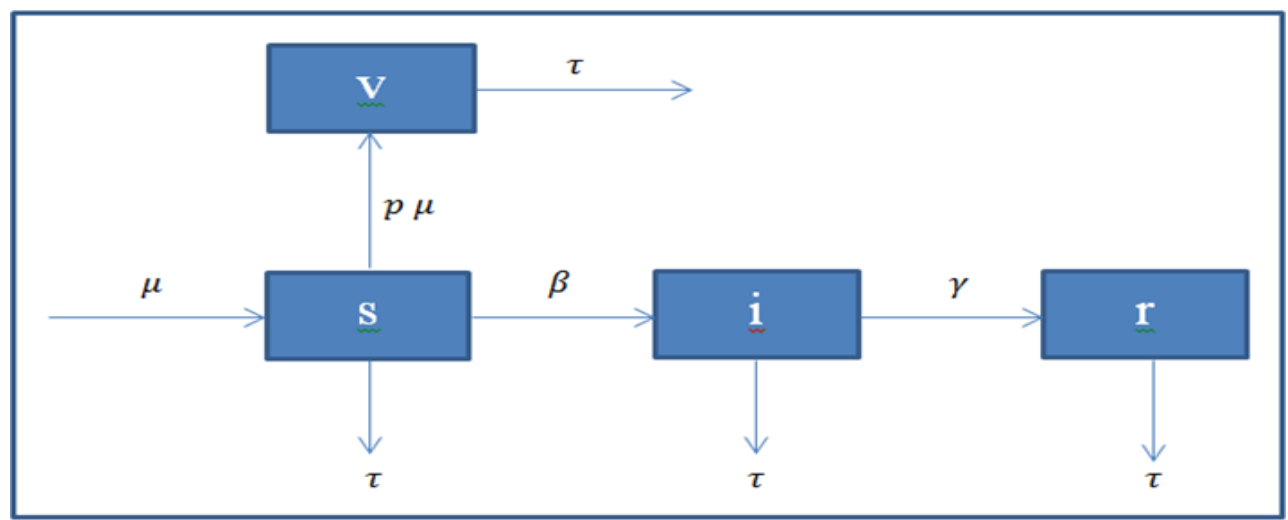

Gambar 2. Diagram Kompartemen Model SIR dengan Vaksinasi

dan dapat dinyatakan sebagai sistem persamaan diferensial, sebagai berikut:

$$
\begin{aligned}
& \frac{d s}{d t}=(1-p) \mu-\beta i s-\tau s \\
& \frac{d i}{d t}=\beta i s-\gamma i-\tau i \\
& \frac{d r}{d t}=\gamma i-\tau r
\end{aligned}
$$




$$
\frac{d v}{d t}=p \mu-\tau v
$$

dimana $v$ adalah kelompok individu yang telah divaksinasi dengan $p$ adalah tingkat vaksinasi, dimana $p \in$ $(0,1)$.

\subsection{Analisis Kestabilan Model}

Dalam penelitian ini akan dibahas perilaku model (1) dengan membandingkan dua kelompok, yaitu kelompok individu yang rentan dan kelompok individu terinfeksi yang dinyatakan sebagai suatu persamaan differensial

$$
\begin{aligned}
& \frac{d s}{d t}=\mu-\beta i s-\tau s \\
& \frac{d i}{d t}=\beta i s-\gamma i-\tau i
\end{aligned}
$$

dan perilaku model (2) dengan membandingkan tiga kelompok, yaitu kelompok individu yang rentan, kelompok individu yang terinfeksi, dan kelompok individu yang sudah divaksinasi dinyatakan sebagai suatu persamaan differensial

$$
\begin{aligned}
& \frac{d s}{d t}=(1-p) \mu-\beta i s-\tau s \\
& \frac{d i}{d t}=\beta i s-\gamma i-\tau i \\
& \frac{d v}{d t}=p \mu-\tau v
\end{aligned}
$$

\subsection{Model SIR tanpa Vaksinasi}

Terdapat dua titik ekuilibrium dari model (3) yang menggambarkan dua keadaan, yaitu: titik ekuilibrium bebas penyakit, $E_{0}=(s, i)=\left(\frac{\mu}{\tau}, 0\right)$, menandakan keadaan bahwa tidak ada individu yang terinfeksi, artinya populasi bebas dari penyakit dan titik ekuilibrium endemik, $E_{l}=\left(s^{*}, i^{*}\right)$, dimana $s^{*}=$ $\left(\frac{\gamma+\tau}{\beta}\right)$ dan $i^{*}=\left(\frac{\beta \mu-\tau(\gamma+\tau)}{\beta(\gamma+\tau)}\right)$, menandakan keadaan bahwa terdapat individu yang terinfeksi dalam populasi. Titik ekuilibrium endemik $E_{1}$ ada jika $\beta \mu>\tau(\gamma+\tau)$. Nilai ambang batas diperoleh berdasarkan titik ekuilibrium endemik $E_{1}$ dengan mengasumsikan $i>0$, yaitu $\frac{\beta \mu-\tau(\gamma+\tau)}{\beta(\gamma+\tau)}>0$. Definisikan $R_{0}=\frac{\beta \mu}{\beta(\gamma+\tau)}$ adalah nilai ambang batas.

Selanjutnya dengan melinierisasi sistem (3) diperoleh matriks Jacobian

dimana matriks Jacobian di titik ekuilibrium $E_{0}$ adalah

$$
J=\left[\begin{array}{cc}
-\beta i-\tau & -\beta s \\
\beta i & \beta s-\gamma-\tau
\end{array}\right],
$$

$$
J_{E_{0}}=\left[\begin{array}{cc}
-\tau & -\frac{\beta \mu}{\tau} \\
0 & \frac{\beta \mu-\tau(\gamma+\tau)}{\tau}
\end{array}\right],
$$

dan matriks Jacobian di titik ekuilibrium $E_{1}$ adalah

$$
J_{E_{1}}=\left[\begin{array}{cc}
-\frac{\beta \mu}{\gamma+\tau} & -(\gamma+\tau) \\
\frac{\beta \mu}{\gamma+\tau}-\tau & 0
\end{array}\right] .
$$

Persamaan karakteristik dari matriks Jacobian $J_{E_{0}}$ adalah 


$$
\begin{gathered}
\left|J_{E_{0}}-I \lambda\right|=0, \\
\left|\begin{array}{cc}
-\tau-\lambda & -\frac{\beta \mu}{\tau} \\
0 & \beta-\gamma-\tau-\lambda
\end{array}\right|=0,
\end{gathered}
$$

sehingga diperoleh nilai-nilai eigen $\lambda_{1}=-\tau$ dan $\lambda_{2}=\frac{\beta \mu-\tau(\gamma+\tau)}{\tau}$. Sementara itu, persamaan karakteristik dari matriks Jacobian $J_{E_{1}}$ adalah

$$
\begin{gathered}
\left|J_{E_{1}}-I \lambda\right|=0, \\
\left|\begin{array}{cc}
\frac{-\mu \beta}{\gamma+\tau}-\lambda & -(\gamma+\tau) \\
\frac{\mu \beta}{\gamma+\tau}-\tau & -\lambda
\end{array}\right|=0,
\end{gathered}
$$

sehingga diperoleh nilai-nilai eigen

$$
\lambda_{1,2}=\frac{1}{2}\left(-\frac{\mu \beta}{\gamma+\tau} \pm \sqrt{\frac{\mu^{2} \beta^{2}}{(\gamma+\tau)^{2}}-4(\beta \mu-\tau(\gamma+\tau))}\right) .
$$

Klasifikasi kestabilan dari titik ekuilibrium berdasarkan pada nilai eigen dari matriks Jacobian. Titik ekuilibrium bebas penyakit, $\mathrm{E}_{0}$, mempunyai nilai eigen $\lambda_{1}=-\tau$ dan $\lambda_{2}=\frac{\beta \mu-\tau(\gamma+\tau)}{\tau}$. Semua nilai eigen bernilai riil negatif jika $\beta \mu-\tau(\gamma+\tau)<0$ atau $\mathrm{R}_{0}<1$, sehingga dapat disimpulkan bahwa $\mathrm{E}_{0}$ stabil asimtotik jika $\mathrm{R}_{0}<1$ dan $\mathrm{E}_{0}$ tidak stabil jika $\mathrm{R}_{0}>1$. Titik ekuilibrium endemik, $\mathrm{E}_{1}$, mempunyai nilai eigen

$$
\begin{aligned}
& \lambda_{1,2}=\frac{1}{2}\left(-\frac{\mu \beta}{\gamma+\tau} \pm \sqrt{\frac{\mu^{2} \beta^{2}}{(\gamma+\tau)^{2}}-4(\beta \mu-\tau(\gamma+\tau))}\right) \\
& \quad=\frac{1}{2}\left(-\tau R_{0} \pm \sqrt{D_{0}}\right),
\end{aligned}
$$

dimana $D_{0}=\left(-\tau R_{0}\right)^{2}-4(\beta \mu-\tau(\gamma+\tau)$.

Kedua nilai eigen $\lambda_{1}$ dan $\lambda_{2}$ bergantung pada nilai di dalam akar $\left(\mathrm{D}_{0}\right)$. Jika $\mathrm{D}_{0}>0$, maka terdapat dua akar riil negatif dengan syarat $\sqrt{D_{0}}<\tau R_{0}$, dan terdapat dua akar riil berbeda tanda dengan syarat $\sqrt{D_{0}}>\tau R_{0}$. Jika $D_{0}<0$, maka terdapat nilai eigen kompleks dengan bagian riil negative. Berdasarkan kondisi tersebut, maka semua nilai eigen dengan bagian riil bernilai negatif jika $R_{0}>1$. Artinya bahwa titik ekuilibrium endemik $E_{1}$ stabil asimtotik jika $R_{0}>1$ dan tidak stabil jika $R_{0}<1$.

\subsection{Model SIR dengan Vaksinasi}

Terdapat dua titik ekuilibrium model (4) yang menggambarkan dua keadaan, yaitu: titik ekuilibrium bebas penyakit, $\mathrm{E}_{\mathrm{v}}=(\mathrm{s}, \mathrm{i}, \mathrm{v})=\left(\frac{(1-p) \mu}{\tau}, 0, \frac{p \mu}{\tau}\right)$, menandakan keadaan bahwa tidak ada individu yang terinfeksi, artinya populasi bebas dari penyakit dan titik ekuilibrium endemik, $E_{v^{*}}=(s, i, v)$, dimana $s=$ $\left(\frac{\gamma+\tau}{\beta}\right), \mathrm{i}=\left(\frac{(1-p) \beta \mu-\tau(\gamma+\tau)}{\beta(\gamma+\tau)}\right)$ dan $\mathrm{v}=\left(\frac{p \mu}{\tau}\right)$, adalah keadaan yang menandakan keadaan bahwa terdapat individu yang terinfeksi dalam populasi.

Titik ekuilibrium endemik, $E_{v^{*}}$ ada jika $(1-p) \beta \mu>\tau(\gamma+\tau)$. Nilai ambang batas diperoleh berdasarkan titikekuilibrium endemik $E_{v^{*}}$ dengan mengasumsikan $i>0$, yaitu

$$
\frac{(1-p) \beta \mu-\tau(\gamma+\tau)}{\beta(\gamma+\tau)}>0 .
$$

Definisikan $R_{v}=(1-p) R_{0}$ adalah nilai ambang batas.

Selanjutnya dengan melinierisasi sistem (4) diperoleh matriks Jacobian 


$$
J=\left[\begin{array}{ccc}
-\beta i-\tau & -\beta s & 0 \\
\beta i & \beta s-\gamma-\tau & 0 \\
0 & 0 & -\tau
\end{array}\right]
$$

Matriks Jacobian di titik ekuilibrium $E_{\mathrm{v}}$ adalah

$$
J_{E_{v}}=\left[\begin{array}{ccc}
-\tau & -\frac{\beta \mu(1-p)}{\tau} & 0 \\
0 & \frac{\mu \beta(1-p)-\tau(\gamma+\tau)}{\tau} & 0 \\
0 & 0 & -\tau
\end{array}\right]
$$

Matriks Jacobian di titik ekuilibrium $E_{v^{*}}$ adalah

$$
J_{E_{v^{*}}}=\left[\begin{array}{ccc}
-\frac{\beta \mu(1-p)}{\tau} & -(\gamma+\tau) & 0 \\
\frac{\mu \beta(1-p)-\tau(\gamma+\tau)}{\tau+\gamma} & 0 & 0 \\
0 & 0 & -\tau
\end{array}\right] .
$$

Persamaan karakteristik dari matriks Jacobian $J_{E_{v}}$ adalah

$$
\begin{gathered}
\left|J_{E_{v}}-I \lambda\right|=0 \\
\left|\begin{array}{ccc}
-\tau-\lambda & -\frac{\beta \mu(1-p)}{\tau} & 0 \\
0 & \frac{\mu \beta(1-p)-\tau(\gamma+\tau)}{\tau}-\lambda & 0 \\
0 & 0 & -\tau-\lambda
\end{array}\right|=0,
\end{gathered}
$$

sehingga diperoleh nilai-nilai eigen :

$\lambda_{1}=-\tau, \lambda_{2}=-\tau$ dan $\lambda_{3}=\frac{\beta \mu(1-p)-\tau(\gamma+\tau)}{\tau}$.

Sementara itu, persamaan karakteristik dari matriks Jacobian $J_{E_{v^{*}}}$ adalah

$$
\begin{gathered}
\left|J_{E_{v^{*}}}-I \lambda\right|=0 \\
\left|\begin{array}{ccc}
-\frac{\beta \mu(1-p)}{\tau}-\lambda & -(\gamma+\tau) & 0 \\
\frac{\mu \beta(1-p)-\tau(\gamma+\tau)}{\tau+\gamma} & -\lambda & 0 \\
0 & 0 & -\tau-\lambda
\end{array}\right|=0,
\end{gathered}
$$

sehingga diperoleh nilai-nilai eigen $\lambda_{1}=-\tau$ dan

$$
\lambda_{2,3}=\frac{1}{2}\left(-\frac{\mu \beta(1-p)}{\gamma+\tau} \pm \sqrt{\frac{\mu^{2} \beta^{2}(1-p)^{2}}{(\gamma+\tau)^{2}}-4(\mu \beta(1-p)-\tau(\gamma+\tau))}\right)
$$

Klasifikasi kestabilan dari titil ekuilibrium berdasarkan pada nilai eigen dari matriks Jacobian. Titik ekuilibrium bebas penyakit, $\mathrm{E}_{0}$, mempunyai nilai eigen $\lambda_{1}=-\tau, \lambda_{2}=-\tau$ dan $\lambda_{3}=\frac{\mu \beta(1-p)-\tau(\gamma+\tau)}{\tau}$. Semua nilai eigen bernilai riil negatif jika $\mu \beta(1-\mathrm{p})-\tau(\gamma+\tau)<0$ atau $\mathrm{R}_{0}(1-\mathrm{p})=R_{v}<1$, sehingga dapat disimpulkan bahwa $E_{v}$ stabil asimtotik jika $R_{v}<1$ dan $E_{v}$ tidak stabil jika $R_{v}>1$. Titik ekuilibrium endemik, $E_{v^{*}}$ mempunyai nilai eigen

$$
\begin{gathered}
\lambda_{1}=-\tau \text { dan } \lambda_{2,3}=\frac{1}{2}\left(-\frac{\mu \beta(1-\mathrm{p})}{\gamma+\tau} \pm \sqrt{\frac{\mu^{2} \beta^{2}(1-p)^{2}}{(\gamma+\tau)^{2}}-4(\mu \beta(1-\mathrm{p})-\tau(\gamma+\tau))}\right) \\
=\frac{1}{2}\left(-\tau R_{v} \pm \sqrt{D_{v}}\right),
\end{gathered}
$$

dimana $D_{v}=\left(-\tau R_{v}\right)^{2}-4(\mu \beta(1-\mathrm{p})-\tau(\gamma+\tau)$.

Ketiga nilai eigen $\lambda_{1}, \lambda_{2}$ dan $\lambda_{3}$ bergantung pada nilai di dalam akar $\left(D_{v}\right)$. Jika $D_{v}>0$, maka terdapat dua akar riil negatif dengan syarat $\sqrt{D_{v}}<\tau R_{v}$, dan terdapat dua akar riil berbeda tanda dengan syarat $\sqrt{D_{v}}>\tau R_{v}$. Jika $D_{\mathrm{v}}<0$, maka terdapat nilai eigen kompleks dengan bagian riil negatif. Berdasarkan kondisi tersebut, maka semua nilai eigen dengan bagian riil bernilai negatif jika $R_{\mathrm{v}}>1$. Artinya bahwa titik ekuilibrium endemik $E_{v^{*}}$ stabil asimtotik jika $R_{\mathrm{v}}>1$ dan tidak stabil jika $R_{\mathrm{v}}<1$. 


\subsection{Simulasi Numerik}

Simulasi numerik dilakukan untuk mengkonfirmasi solusi analitik yang diperoleh sebelumnya. Parameter yang digunakan dalam simulasi numerik adalah sebagai berikut: $\mu=0.7, \beta=1.98, \tau=0.3$ dan $\gamma=0.5$ [4]. Grafik solusi Sistem (3) dan Sistem (4) dengan nilai awal $s(0)=0.65, i(0)=0.1, v(0)=0.2$ dapat dilihat pada Gambar 3 dan Gambar 4.

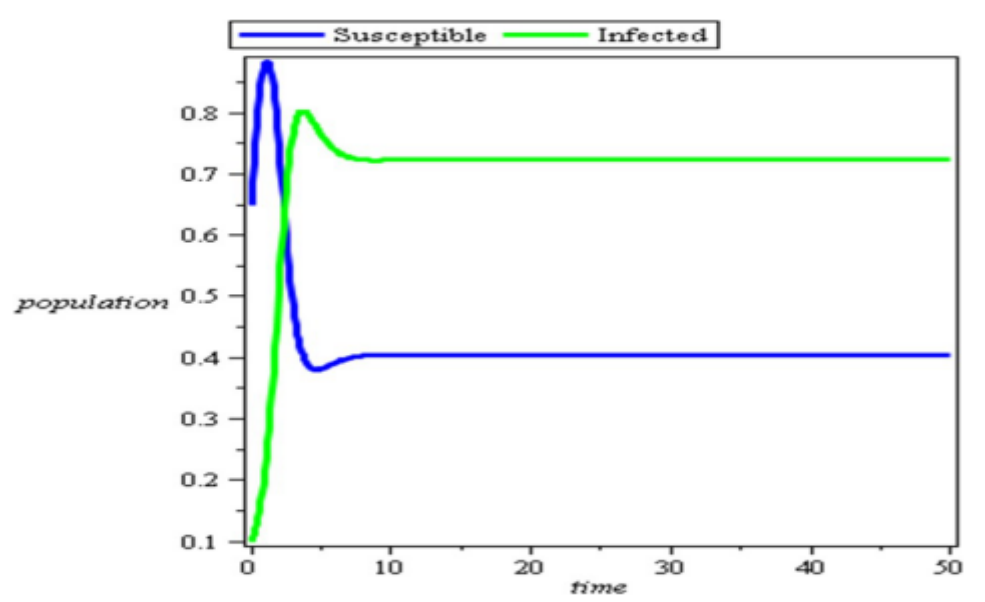

Gambar 3. Grafik Solusi Model SIR Tanpa Vaksinasi (3)

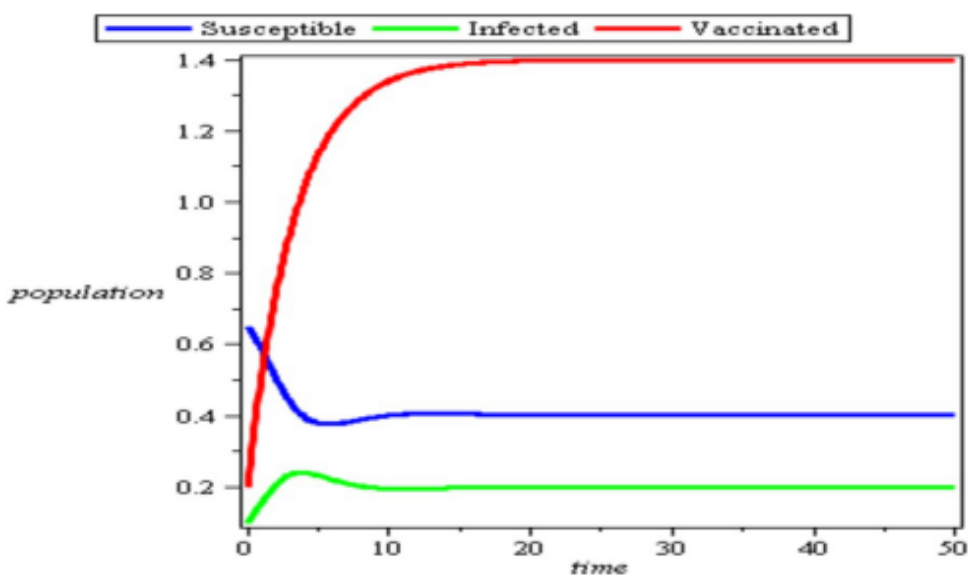

Gambar 4. Grafik Solusi Model Dengan Vaksinasi (4)

Titik ekulibrium endemik dari Sistem (3) adalah $E_{1}=(0.40404,0.72348)$ dan nilai ambang batas adalah $R_{0}=5,775>1$. Dari Gambar 3 dapat dilihat bahwa pada awalnya laju pertumbuhan kelompok yangrentan meningkat sampai waktu $t$ tertentu, kemudian berkurang karena terinfeksi dan masuk ke kelompok individu yang terinfeksi, setelah itu mengalami kenaikan lagi yang disebabkan karena berkurangnya individu yang menginfeksi sampai laju pertumbuhan tidak mengalami perubahan atau mengalami kesetimbangan padatitik tertentu. Sementaraitu laju pertumbuhan kelompokyang terinfeksi meningkat sampai waktu $t$ tertentu karena masuknya individu rentan yang sudah terinfeksi, kemudian turun sampai tidak mengalami perubahan atau mengalami kesetimbangan pada titik tertentu. Ini berarti bahwa individu yang terinfeksi masih ada di dalam populasi.

Titik ekuilibrium endemik dari Sistem (4) adalah $E_{v^{*}}=(0.40404,0.19848,1.4)$ dan nilai ambang batas adalah $R_{v}=2,31>1$. Dari Gambar 4 dapat dilihat bahwa dengan mempertimbangkan vaksinasi dengan tingkat vaksinasi $p=0.6$, laju pertumbuhan individu yang terinfeksi berkurang dibandingkan tanpa adanya vaksinasi dan akhirnya tidak mengalami perubahan atau mengalami kesetimbangan pada titik tertentu. Ini berartibahwa individu yang terinfeksi masih ada di dalam populasi. 


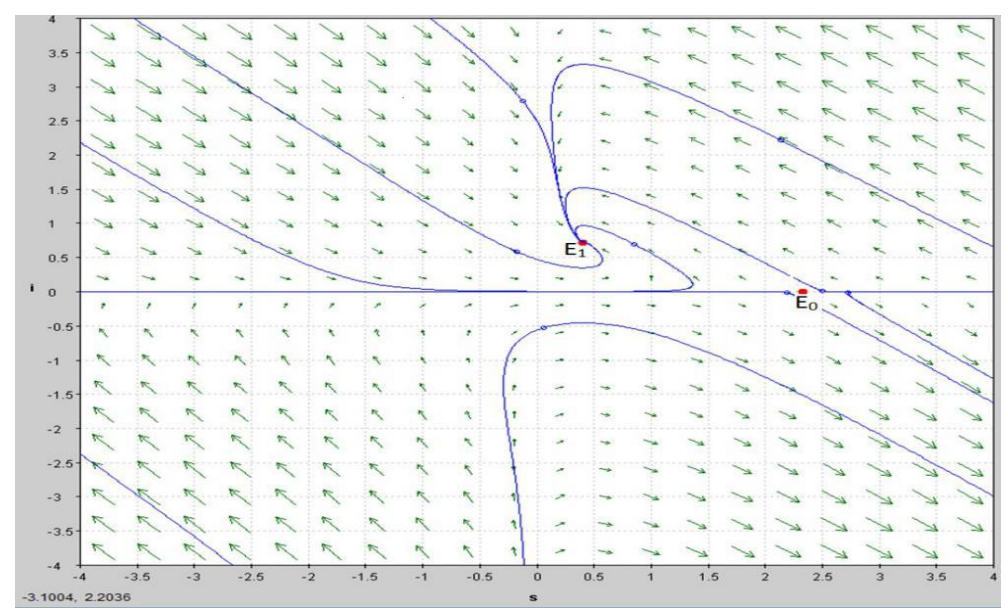

Gambar 5. Potret Fase Model 3

Selanjutnya kestabilan model di sekitar titik ekuilibriummya diperlihatkan oleh Gambar 5 dan Gambar 6. Gambar 5 memperlihatkan kestabilan disekitar titik ekuilibrium bebas penyakit $E_{0}=(2,333,0)$ dengan nilai eigen yaitu $\lambda_{1}=-0,3$ dan $\lambda_{2}=3,82$. Nilai eigen yang diperoleh adalah riil dan berbeda tanda, maka tipe titik ekuilibrium adalah sadle dan tidak stabil, dimana trajektori pada awalnya menuju titik $E_{0}$, tetapi kemudian menjauhi titik ekuilibrium tersebut. Sedangkan kestabilan disekitar titik ekuilibrium endemik $E_{1}=$ $(0.40404,0.72348)$ dengan nilai eigen yaitu $\lambda_{1,2}=\frac{1}{2}\left(-\tau R_{0} \pm \sqrt{D_{0}}\right)$, dimana $D_{0}=-1,58244375$. Nilai eigen yang diperoleh adalah kompleks dengan bagian riil $\alpha=-\tau \mathrm{R}_{0}=-1,7325$, maka tipe titik ekuilibrium dikatakan fokus stabil, dimana trajektori menuju titik tersebut.

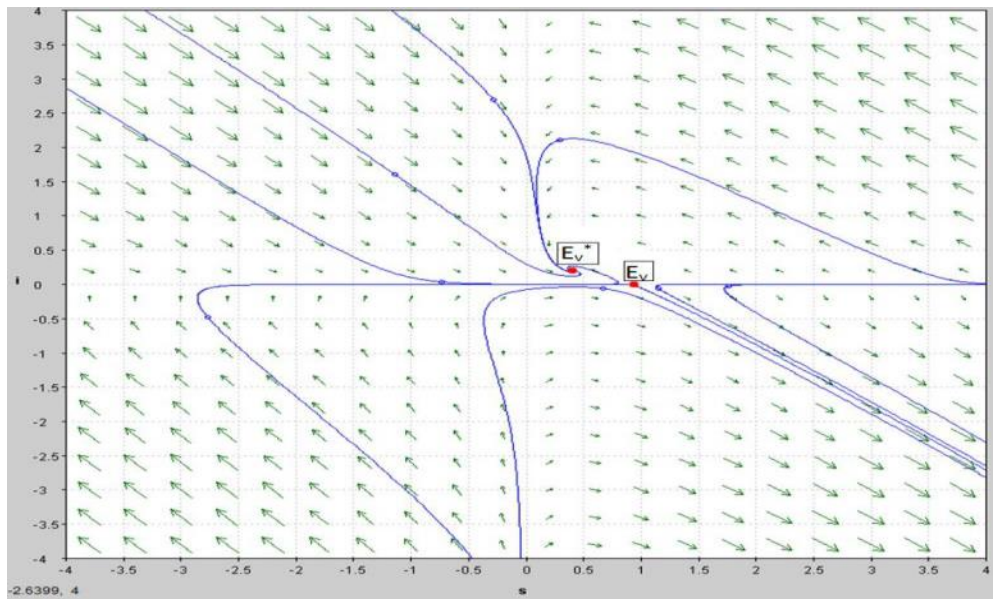

Gambar 6. Potret Fase Model 4

Gambar 6 memperlihatkan kestabilan disekitar titik ekuilibrium bebas penyakit $E_{\mathrm{v}}=(0.9333,0,1.4)$ dengan nilai eigen yaitu $\lambda_{1}=-0.3, \lambda_{2}=-0.3$ dan $\lambda_{3}=1,048$. Nilai eigen yang diperoleh adalah riil dan berbeda tanda, maka tipe titik ekuilibrium adalah sadle dan tidak stabil, dimana trajektori pada awalnya menuju titik $E_{\mathrm{v}}$, tetapi kemudian menjauhi titik ekuilibrium tersebut. Sedangkan kestabilan disekitar titik ekuilibrium endemik $E_{v^{*}}=(0.40404,0.19848,1.4)$ dengan nilai eigen yaitu $\lambda_{1}=-0.3$ dan $\lambda_{2,3}=\frac{1}{2}\left(-\tau R_{v} \pm\right.$ $\sqrt{D_{v}}$, dimana $D_{\mathrm{v}}=-0,777351$. Nilai eigen yang diperoleh adalah kompleks dengan bagian riil $\alpha=-\tau \mathrm{R}_{\mathrm{v}}=$ $-2,31$, maka tipe titik ekuilibrium dikatakan fokus stabil, dimana trajektori menuju titik tersebut. 


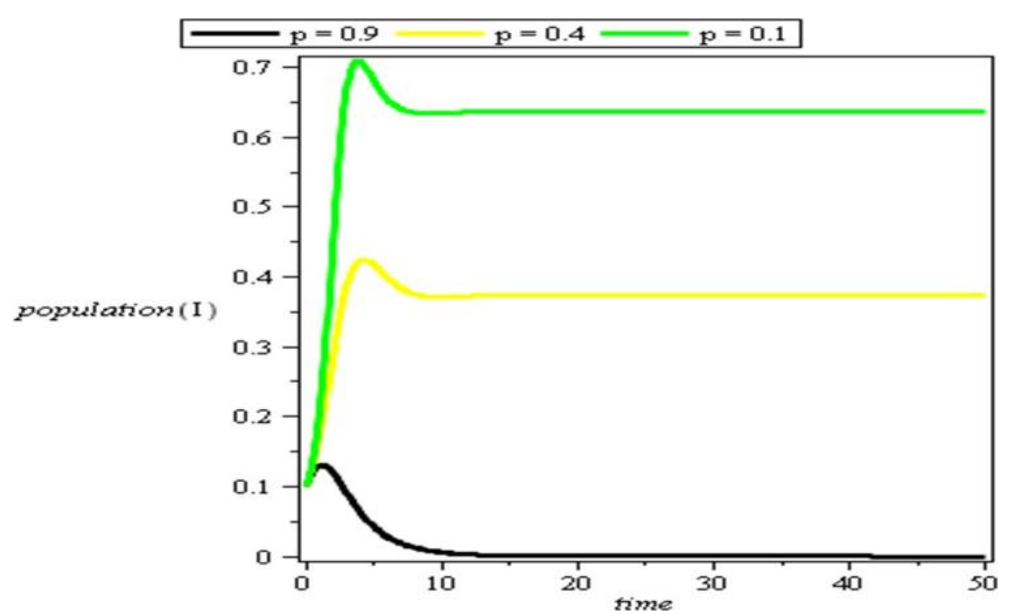

Gambar 7. Potret Fase Model 4 untuk populasi I(t)

Laju perubahan kelompok individu yang terinfeksi dengan diberikannya beberapa tingkat vaksinasi, yaitu $p 1=$ $0,9, p 2=0,4, p 3=0,1$, diperlihatkan pada Gambar 7. Dari gambar dapat dilihat bahwa kelompok individu yang yang terinfeksi menurun seiring dengan besarnya tingkat vaksin yang diberikan.

\section{KESIMPULAN}

1. Penelitian membahas dua model penyebaran penyakit yaitu model SIR tanpa dan dengan vaksinasi.

2. Perilaku solusi kedua model dikaji dengan menganalisis kestabilan kedua model di sekitar titik ekuilibriumnya.

3. Nilai ambang batas yang berkaitan dengan kestabilan tersebut dinotasikan sebagai $R_{0}$ untuk model tanpa vaksinasi dan $R_{v}$ untuk model dengan vaksinasi.

4. Titik ekuilibrium endemik model tanpa vaksinasi $E_{1}$ stabil jika $R_{0}>1$ dan tidak stabil jika $R_{0}<$ 1 , sedangkan titik ekuilibrium endemic model dengan vaksinasi $E_{v^{*}}$ stabil jika $R_{v}>1$ dan tidak stabil jika $R_{v}<1$.

5. Hasil numerik menyatakan bahwa dengan diberikannya vaksinasi sebesar $p$ pada individu yang baru masuk ke dalam populasi rentan mengakibatkan berkurangnya individu terinfeksi.

6. Semakin tinggi tingkat vaksinasi yang diberikan semakin turun tingkat populasi terinfeksi.

\section{DAFTAR PUSTAKA}

[1] R.M. Anderson and R.M May, Infectious Diseases of Humans: Dynamic and Control, 1991.

[2] Beaglehole and Bonita. Basic Epidemiology. World Health Organization: Geneva, 1993.

[3] J.R. Brannan and W.E. Boyce, Differential Equations: An Introduction to Modern Methods and Applications. John Wiley and Sons: New York, 2011.

[4] S. Chauhan, O.P. Misra and J. Dhar, "Stability analysis of SIR model with vaccination", American Journal of Computational and Applied Mathematics, vol. 4, no. 1, pp. 17-23, 2014.

[5] N. Finizio and G. Ladas, Persamaan Diferensial Biasa dengan Penerapan Modern, Edisi Kedua, Terjemahan Bahasa Indonesia. Erlangga: Jakarta, 1998.

[6] B. Fred and C. Carlos-Chavez, Mathematical Models in Population Biology and Epidemiology. Spinger: Vancouver, B. C., Canada, 2000.

[7] W.G. Kelley and A.C. Peterson, The Theory of Differential Equations. Springer-Verlag: New York, 2010.

[8] W.O. Kermack and A.G. Mackendrick, "A contribution to mathematical theory of epidemic", Proc. Roy. Soc. Lond, A 115, pp. 700-721. 1927.

[9] S. Lynch, Dynamical System with Aplication Using Mathematics. Birkhuser Boston: Cambridge, 2007.

[10] M.J. Keeling and P. Rohani, Modeling Infectious Disease: In Humans and Animals. Princenton University Press, 2008.

[11] M. Ehrhardt, J.Gasper and S. Kilianova, "SIR-based mathematical modeling of infectious disease with vaccination and waning Immunity", Journal of Computational Science, vol. 37, pp. 1-26, 2019. 
[12] T.K. Kar and A. Batabyal, "Stability analysis and optimal control of an SIR epidemic model with vaccination", Biosystem, vol. 104, no. 2-3, pp. 127-135, 2011.

[13] M. Choisy, J.F. Guegan and P. Rohani, Mathematical Modeling of Infectious Diseases Dynamics, Encyclopedia of Infectious Diseases: Modern Methodologies. John Wiley \& Sons, Inc, 2007.

[14] G. Zaman, Y.H. Kang, H. Jung and P.N. Okolo, "Stability analysis and optimal vaccination of an SIR epidemic model", Biosystems, vol. 93, no. 3, pp. 240-249, 2008.

[15] H.W. Hethcote, The Mathematic model of Infectious Diseases. Lowa City: Department of Mathematics, University of Lowa, 2000. 